\title{
Pengelolaan Limbah Industri PT. Apac Inti Corpora Bawen Semarang
}

\section{Indriana Dwi Mutiara Sari}

\section{Indriana Dwi Mutiara Sari;}

Indriana Dwi Mutiara Sari, Fakultas Hukum Universitas Diponegoro; Jl. Prof. Soedarto; Semarang; 50275; Indonesia

AR T ICLEINFO

Article history:

Received 2018-10-21

Received in revised form

2018-11-29

Accepted 2018-12-01

Kata kunci: Pengelolaan Limbah, Lingkungan Hidup, PT. Apac Inti Corpora.

Keywords: Waste Management, Living environment, PT. Apac Inti Corpora.

\section{Abstrak}

Berlakunya Undang-Undang Nomor 32 Tahun 2009 tentang Perlindungan dan Pengelolaan Lingkungan Hidup, yang menyatakan bahwa pengelolaan dan perlindungan lingkungan hidup perlu dilakukan dengan sebaik-baiknya berdasarkan dengan manfaat yang diberikan oleh lingkungan hidup itu sendiri. Fenomena pencemaran limbah industry di Bawen, Kabupaten Semarang mengancam kelestarian fungsi lingkungan hidup. Pencemaran lingkungan hidup akibat pembuangan limbah industri, akan mengganggu kehidupan masyarakat dan dapat menurunkan kualitas lingkungan hidup secara berkesinambungan. Adapun permasalahan penelitian ini adalah bagaimana tata cara pengelolaan limbah di PT. Apac Inti Corpora dan hambatan apa yang dialami dalam proses pengelolaan limbah di PT. Apac Inti Corpora. Berdasarkan hasil penelitian, diketahui bahwa PT. Apac Inti Corpora menggunakan Peraturan Daerah Provinsi Jawa Tengah Nomor 5 Tahun 2012 Tentang Perubahan Atas Peraturan Daerah Provinsi Jawa Tengah Nomor 10 Tahun 2004 Tentang Baku Mutu Air Limbah sebagai pedoman untuk tata cara pengelolaan air limbah.

\section{Abstract}

The enactment of Law No. 32 of 2009 on the Protection and Management of the Environment, which states that managing and protecting the environment needs to be done as well as possible, based on the benefits provided by the environment itself. The industrial waste pollution phenomenon in Bawen, Semarang had threaten the sustainability of the environment functions. Environmental pollution due to industrial waste disposal will interfere the quality of people's lifes and can degrade the quality of the environment on an ongoing basis. The problem of this research is how the waste procedure, PT. Apac Inti Corpora manages its waste disposal and its obstacles.Based on this research, known that PT. Apac Inti Corpora is using the Central Java Provincial Regulation No. 5 of 2012 on the Amendment of the Central Java Provincial Regulation No. 10 of 2004. 


\section{Pengelolaan Limbah Industri PT. Apac Inti Corpora Bawen Semarang}

Indriana Dwi Mutiara Sari

\section{Latar Belakang}

Manusia hidup di dunia menentukan lingkungannya atau ditentukan lingkungannya. Perubahan lingkungan sangat ditentukan oleh sikap maupun perlindungan manusia pada lingkungannya. Alam yang ada secara fisik dapat dimanfaatkan untuk kepentingan manusia dalam mengupayakan kehidupan yang lebih baik dan sehat menjadi tidak baik dan tidak sehat dan dapat pula sebaliknya, apabila pemanfaatannya tidak digunakan sesuai dengan kemampuan serta melihat situasinya.

Masa globalisasi seperti sekarang ini, manusia dituntut untuk dapat bekerja agar kebutuhan hidupnya terpenuhi. Dengan adanya trend globalisasi pada pekerjaan, mengakibatkan terjadinya persaingan yang ketat untuk mendapatkan pekerjaan. Hal ini ditandai dengan semakin tingginya syarat dalam memperoleh pekerjaan yang layak, baik dalam segi pengetahuan mengenai teknologi yang ada dan pengetahuan yang luas. Namun hal ini tidak diimbangi dengan sarana dan prasarana untuk menunjang hal tersebut, terutama bagi masyarakat dengan tingkat ekonomi rendah. Tidak ada yang dapat memfasilitasi atau menjembatani mereka untuk menempuh pengetahuan dan pendidikan yang layak sedangkan dunia menuntut mereka untuk dapat memenuhi kebutuhan mereka dengan persyaratan diatas kemampuan yang mereka dapat.

Manusia dalam hidupnya harus melindungi dan mengamankan "alam" agar dapat terselenggara secara teratur dan pasti, pula agar dapat diikuti serta ditaati oleh semua pihak, maka perlu perlindungan dan pengamanan tersebut dituangkan dalam peraturan hukum. Di dalam UndangUndang Nomor 32 Tahun 2009 tentang Perlindungan dan Pengelolaan Lingkungan Hidup mengatur adanya Lingkungan Hidup dalam pengertian ekologi tidak mengenal batas wilayah, baik wilayah negara maupun wilayah administratif. Akan tetapi, lingkungan hidup yang berkaitan dengan pengelolaan harus jelas batas wilayah wewenang pengelolaannya. Lingkungan Hidup Indonesia sebagai suatu ekosistem terdiri atas berbagai subsistem, yang mempunyai aspek sosial, budaya, ekonomi dan geografi dengan corak ragam yang berbeda yang mengakibatkan daya dukung dan daya tampung lingkungan hidup yang berlainan. Oleh karena itu, dikembangkannya suatu sistem dengan keterpaduan sebagai ciri utamanya. Dan lahir jenis hukum yang secara khusus diciptakan dengan tujuan untuk memelihara dan melindungi lingkungan hidup yang disebut "Hukum Lingkungan Hidup" atau disingkat dengan "Hukum Lingkungan" (Abdurrahman, 1983).

Kebutuhan masyarakat yang tinggi tentu diperlukan beberapa aspek yang dibutuhkan, apalagi untuk mendirikan suatu perusahaan atu pabrik. Selain membutuhkan lahan yang strategis untuk mendirikan usaha juga diperlukan SDM yang dapat menunjang berjalannya suatu perusahaan atau pabrik. Namun sebagian besar dari bahan-bahan yang digunakan dalam industri terdiri dari bahan kimia. Sebagai dampak samping dari penggunaan bahan-bahan kimia tersebut adalah semakin meningkatnya masalah lingkungan yang masuk diantaranya adalah masalah limbah.

Menyadari setiap hari terjadi pencemaran dan/atau perusakan lingkungan hidup, baik yang diakibatkan karena proses alam maupun yang diakibatkan oleh pembangunan melalui aktivitas manusia, maka hampir semua negara mempunyai keinginan bagaimana agar pembangunan berjalan tanpa merusak atau mencemari lingkungan hidup. Untuk itu, timbul pemikiran agar membuat suatu standart yang dijadikan patokan dasar dalam kategori pencemaran atau perusakan lingkungan yang lazim disebut "Baku Mutu Lingkungan" (Abdurrahman, 1983).

Aspek pengawasan pemerintah secara obyektif dapat dilihat bahwa pembangunan di bidang industri mempunyai kelebihan dan kelemahan. Pengawasan sangat diperlukan karena se- 
ring kali terjadi suatu penyimpangan dalam proses produksi yang dilakukan. Penyimpangan yang sering terjadi adalah adanya pelanggaran yang berkaitan dengan kelestarian lingkungan, sperti sistem pengelolaan limbah industri yang tidak sempurna. Usaha tersebut tidak memenuhi standard baku mutu lingkungan yang telah ditetapkan dalam Undang Undang Lingkungan Hidup. Baku mutu lingkungan hidup adalah ukuran batas atau kadar makhluk hidup, zat, energi atau komponen yang ada atau harus ada dan/atau unsur pencemar yang ditenggang keberadaannya dalam suatu sumber daya tertentu sebagai unsur lingkungan hidup.

PT. Apac Inti Corpora yang bergerak dibidang tekstil terletak di Jalan Soekarno Hatta Km 32 Desa Harjosari, Bawen Kabupaten Semarang yang letaknya berdekatan dengan pemukiman warga. Dari kegiatan pengolahan tekstil tersebut dapat menghasilkan limbah cair dan padat yang dapat mengakibatkan pencemaran atau kerusakan lingkungan. Maka dari itu PT. Apac Inti Corpora melakukan beberapa proses pengolahan limbah yang telah dihasilkan dari beberapa kegiatan yang ada pada perusahaan. Penanganan limbah ini dilaksanakan oleh Unit Pengolahan Limbah atau biasa disingkat WWT. Limbah yang dihasilkan dari proses produksi tersebut tidak boleh sampai mencemari lingkungan sekitar pabrik.

\section{Metode}

Metode pendekatan dalam penelitian ini adalah yuridis empiris. Penelitian hukum dengan meneliti data sekunder pada awalnya untuk kemudian dilanjutkan dengan penelitian terhadap data primer di lapangan, dimana penelitian hukum mengenai pemberlakuan atau implementasi ketentuan hukum normatif (kodifikasi, undang-undang atau kontrak) secara in action. Implementasi in action diharapkan akan berlangsung secara sempurna apabila rumusan ketentuan hukum normatifnya jelas, tegas dan lengkap. Pendekatan yuridis mengandung arti pendekatan dari aspeknya hukum- nya,dalam hal ini Undang-Undang Nomor 32 Tahun 2009. Sedangkan pendekatan empiris digunakan untuk menganalisis hukum yang dilihat sebagai perilaku masyarakat yang berpola dalam kehidupan masyarakat yang selalu berinteraksi dan berhubungan dalam aspek kemasyarakatan.

\section{Pembahasan}

\subsection{Limbah Industri PT. Apac Inti Corpora}

Lingkungan hidup adalah kesatuan ruang dengan semua benda, daya, keadaan dan makhluk hidup, termasuk manusia dan perilakunya, yang mempengaruhi kelangsungan perikehidupan dan kesejahteraan manusia serta makhluk hidup yang lain. Pengelolaan dan perlindungan lingkungan hidup adalah upaya sistematis dan terpadu yang dilakukan untuk melestarikan fungsi lingkungan hidup dan mencegah terjadinya pencemaran dan/ atau kerusakan lingkungan hidup yang meliputi perencanaan, pemanfaatan, pengendalian, pemeliharaan, pengawasan dan penegakan hukum.

Lingkungan hidup meliputi air, lautan, udara, kekayaan alam yang terkandung didalam bumi, semuanya adalah ciptaan Tuhan Yang Maha Esa. Sebagai ciptaan Tuhan maka semua yang ada di bumi dan segala isinya dan udara diatasnya serta laut, perlu dijaga kelestariannya oleh seluruh umat manusia di seluruh dunia ini (Siswanto, 2015).

Empat elemen penting dalam pengelolaan lingkungan hidup, yaitu: (Bruce, 2000:1) 1) Perubahan; 2) Kompleksitas; 3) Ketidakpastian; 4) Konflik. Antara lingkungan hidup dan kehidupan manusia tidak dapat dipisahkan. Manusia hidup didunia menentukan lingkungannya atau di tentukan oleh lingkungan. perubahan lingkungan sangat ditentukan oleh sikap maupun perlindungan manusia pada lingkungannya. Alam yang ada secara fisik dapat dimanfaatkan untuk kepentingan manusia dalam mengupayakan kehidupan yang lebih baik dan sehat menjadi tidak baik dan tidak sehat begitu pula sebaliknya, apabila pemanfaatannya tidak dilaksanakan dengan sesuai sebagaimana 


\section{Pengelolaan Limbah Industri PT. Apac Inti Corpora Bawen Semarang}

Indriana Dwi Mutiara Sari

mestinya. Sudah seharusnya kita sebagai manusia harus menjaga dan melestarikan lingkungan hidup dengan semaksimal mungkin. Hal ini dikarenakan kita hanya bisa memanfaatkan tanpa bisa merawatnya atau melestarikannya maka suatu saat nanti kita tidak dapat hidup dengan lingkungan yang sehat dan nyaman.

Semakin maju dan berkembangnya suatu masyarakat serta semakin berkembangnya budaya konsumtif masyarakat membuat beberapa pelaku usaha menjadikan ini sebagai suatu celah atau keuntungan. Perkembangan dan pengembangan corak dan gaya hidup manusia sejak zaman revolusi sebagian besar disebabkan karena teknologi yang lebih baik untuk menggali, mengolah dan memanfaatkan bahan alam untuk berbagai keperluan manusia. Untuk memenuhi gaya hidup konsumtif masyarakat sekarang ini yang dianggap sangatlah besar maka banyak pelaku usaha yang mendirikan beberapa perusahaan atau pabrik.

Limbah adalah buangan yang dihasilkan dari suatu proses produksi baik industri maupun domestik (Rumah Tangga). Dimana masyarakat bermukim, disanalah berbagai jenis limbah akan dihasilkan. Bila ditinjau secara kimiawi, limbah terdiri dari bahan kimia organik dan anorganik. Dengan konsentrasi dan kuantitas tertentu, kehadiran limbah dapat berdampak negatif terhadap lingkungan, terutama bagi kesehatan manusia sehingga perlu dilakukan penanganan terhadap limbah. Tingkat bahaya keracunan yang ditimbulkan oleh limbah tergantung pada jenis dan karakteristik limbah (Supardi, 1994).

Terdapat berbagai penggolongan limbah yang terdapat dalam masyarakat diantaranya adalah: Limbah Padat, Limbah Organik dan Limbah Anorganik, Limbah Kimia, Limbah Berbahaya, Limbah Radioaktif.

Pencemaran mengakibatkan kualitas lingkungan menurun, akan menjadi fatal apabila lingkungan tidak dapat dimanfaatkan sebagaimana fungsi sebenarnya. Hal ini harus disadari, bahwa keadaan lingkungan yang ditata dengan sebaikbaiknya untuk menyangga kehidupan kini dan mendatang dapat berubah dengan cepat. Perubahan ini bukannya menunjukkan perkembangan yang optimis mengarah pada tuntutan zaman, namum justru sebaliknya, krisis lingkungan timbul dimana-mana. Kemunduran demikian diawali dengan gejala pencemaran dan kerusakan yang belum begitu nampak.

Salah satu tujuan utama pengelolaan lingkungan hidup adalah terlaksananya pembangunan berwawasan lingkungan dan terkendalinya pemanfaatan sumber daya alam secara bijaksana. Untuk itu sejak awal perencanaan kegiatan sudah harus memperkirakan perubahan rona lingkungan akibat pembentukan suatu kondisi yang merugikan akibat diselenggarakannya pembangunan.

Menyadari bahwa setiap kegiatan pada dasarnya menimbulkan dampak terhadap lingkungan hidup, maka perlu dengan perkiraan pada perencanaan awal, sehingga dengan cara demikian dapat dipersiapkan langkah pencegahan maupun penanggulangan dampak negatifnya dan mengupayakan dalam bentuk pengembangan dampak positif dari kegiatan tersebut.

Sehubungan dengan hal tersebut diatas, diperlukan penerapan beberapa instrumen hukum lingkungan sebagai berikut: 1) Amdal, Analisa Mengenai Dampak Lingkungan (AMDAL) merupakan hasil studi mengenai dampak suatu kegiatan yang direncanakan terhadap lingkungan hidup yang diperlukan bagi proses pengembalian keputusan. Sedangkan Analisa Dampak Lingkungan (AMDAL) merupakan telaahan secara cermat dan mendalam tentang dampak penting suatu kegiatan yang direncanakan. 2) POKASIH, Pelaksanaan Prokasih menurut Pasal 3 KEPMEN LH No. KEP 35/MENLH/7/1995 bertujuan agar tercapainya kualitas air sungai yang baik, sehingga dapat meningkatkan fungsi sungai dalam menunjang pembangunan yang berkelanjutan dan terciptanya sistem kelembagaan yang mampu melaksanakan 
pengendalian pencemaran air secara efektif dan efisien serta untuk terwujudnya kesadaran dan tanggung jawab masyarakat dalam pengendalian pencemaran air.

Program Kali Bersih tersebut dalam pelaksanaannya mengantisipasi keberhasilannya dengan bertumpu pada beberapa faktor, yaitu: kemampuan untuk memfokuskan Prokasih pada kegiatan yang terbatas, Konsistensi tindakan oleh pimpinan daerah, Kejelasan tindakan oleh pimpinan daerah. Program ini tidak secara keseluruhan dalam mengatasi sumber-sumber pencemaran namun ada skala prioritas dengan membagi dalam 2 dekade, yakni jangka pendek dan jangka panjang.

Prinsip ini dikenal dengan " Polluter must Pay Principle"(PPP), yaitu si pencemar (pengusaha) diharuskan mengeluarkan biaya-biaya atas pencemaran yang timbul dari aktivitas produksi. Konsekuensinya adalah pengusaha akan memperhitungkan biaya-biaya untuk mengatasi pencemaran menjadi bagian dari biaya produksi (production cost). Dengan prinsip ini diharapkan para industriawan dengan sendirinya berikhtiar untuk meminimalkan standard kualitas lingkungan yang berpedoman pada ketentuan-ketentuan yang berlaku dan betulbetul diperhatikan sebagaimana mestinya. Hal ini menentukan telah terjadi pencemaran dari kegiatan industri/pabrik maka yang lazim dipergunakan adalah 2 (dua) buah sistem BML, yaitu: 1. ketentuan yang disebut dengan Effluent Standard, yaitu kadar maksimum limbah yang diperbolehkan waktu meninggalkan pabrik. Kadar atau mutu buangan/ limbah pabrik sewaktu-waktu dapat diketahui/ dilihat berdasarkan sistem deteksi yang ditempatkan ditempat-tempat tertentu di sekitar pabrik, biasanya pada pipa pembuangan limbah atau pada mulut pipa asap pabrik. Sistem deteksi ini berfungsi sebagai meteran untuk memudahkan pengontrolan tingkat pencemaran limbah dari pabrik. Satuansatuan ukuran itu dinyatakan, misalnya dengan ppm (part per million, bagian per sejuta satuan). Kalau disebut kadar BOD (Biological Oxygen De- mand, yaitu kebutuhan oksigen biologis) adalah 200 ppm, maka kadar buangan BOD adalah 200 satuan per sejuta satuan air, misalnya untuk air sungai. 2 . ketentuan yang disebut dengan Stream Standard, yaitu penetapan kadar batas untuk sumber daya tertentu, seperti badan-badan sungai, danau, waduk, perairan pantai, dan lain-lain. Kadar-kadar yang diterapkan ini didasarkan pada kemampuan sumber daya-sumber daya lingkungan beserta sifat peruntukannya. Misalnya, batas kadar buangan/ zat pencemar yang ditemukan untuk ekosistem pariwisata berbeda dengan ekosistem perairan sungai, karena disini sangat berbeda corak ekosistem dan sifat peruntukannya.

Penerapan ketentuan BML lebih memudahkan, bukan saja dalam hubungannya dengan pembinaan lingkungan. Tetapi di samping itu, masyarakat yang mengalami korban dapat dengan mudah mengidentifikasikan pencemaran-pencemaran lingkungan yang terjadi, selain karena industri telah sedemikian rupa melengkapi saranasarana pengontrol/deteksi bahan-bahan buangan yang berasal dari aktivitasnya.

Karena sudah dengan mudahnya pencemaran diidentifikasikan oleh masyarakat (demikian pula pihak polluter, yaitu pabrik), maka klaim kerugian pencemaran dapat dengan mudah diajukan ke pengadilan tanpa keragu-raguan karena ketidak lengkapan data-data dan fakta-fakta kesalahan. Sebaliknya, bagi masyarakat di negara-negara yang belum menerapkan BML, termasuk negara kita, pengidentifikasian suatu kerusakan atau pencemaran sungguh sangat sulit dilakukan.

Sebagaimana diketahui, sekalipun dalam perundang-undangan sudah menyebutkan lebih jelas kriteria atau pengertian pencemaran dan perusakan lingkungan (dalam UUPPLH 2009 terdapat dalam Pasal 1 butir 14 dan butir 17), namun secara hukum sulit menentukan tentang ada tidaknya dan sampai sejauh mana pencemaran lingkungan dari sebuah pabrik. Kalau hanya mengandalkan ketentuan definisi dan kriteria serta unsur-unsur yang dibe- 


\section{Pengelolaan Limbah Industri PT. Apac Inti Corpora Bawen Semarang}

Indriana Dwi Mutiara Sari

rikan seperti tersebut dalam Pasal 1 butir 14 dan 17 UUPPLH.

Tujuan utama pengelolaan limbah adalah untuk mengurangi partikel tercampur, serta membunuh organisme pathogen. Selain itu, diperlukan juga tambahan pengolahan untuk menghilangkan bahan nutrisi, komponen beracun, serta bahan yang tidak dapat didegradasikan agar konsentrasi yang ada menjadi rendah.

Limbah yang ada di PT. Apac Inti Corpora digolongkan menjadi 2, yaitu: 1) Limbah cair B3 karena mengandung zat asam pospat, asam sulfat dan fenol. Dimana dalam Peraturan Pemerintah Republik Indonesia Nomor 74 Tahun 2001 Tentang Pengelolaan Bahan Berbahaya dan Beracun dijelaskan bahwa ketiga zat yang terkandung dalam limbah industri tersebut termasuk dalam Daftar Bahan Berbahaya dan Beracun (B3) yang dipergunakan; 2) Limbah padat B3 terdapat zat fenol, Arsenik (As), Cadmium (Cd) dimana dalam Peraturan Pemerintah Republik Indonesia Nomor 74 Tahun 2001 Tentang Pengelolaan Bahan Berbahaya dan Beracun dijelaskan bahwa ketiga zat yang terkandung dalam limbah industri tersebut termasuk dalam Daftar Bahan Berbahaya dan Beracun (B3) yang dipergunakan. Limbah padat B3 yang sudah berbentuk seperti lumpur atau pasir dimana limbah tersebut sudah tidak dapat diproses sehingga PT. Apac Inti Corpora melakukan penyimpanan sementara disebuah ruangan yang sudah diberi pengaman jika terdapat suatu upaya untuk penanggulangan kecelakaan dan keadaan darurat yang disebabkan oleh limbah padat tersebut. PT. Apac Inti Corpora hanya melakukan penyimpanan sementara dimana limbah padat B3 tersebut selanjutnya akan diserahkan kepada pihak ketiga dimana dalam hal ini yang dimaksud adalah PT. Terang Jaya yang sudah mendapat izin dari Balai Besar Teknologi Pencegahan Pencemaran Industri untuk mengambil alih libah padat B3 tersebut.

Seiring dengan perkembangan industri yang merupakan tulang punggung perekonomian Indonesia, masalah limbah telah menjadi perhatian serius. Ironisnya, perkembangan industri tidak sejalan dengan penanganan limbahnya. Pengadaan sarana pengolahan limbah yang masih dianggap memberatkan bagi sebagian pelaku industri.

Setiap perusahaan memiliki caranya tersendiri dalam menangani buangan/limbah hasil produksinya, tetapi setiap perusahaan pasti memiliki tujuan yang sama yaitu, agar buangan atau limbah yang dihasilkan memenuhi baku mutu yang telah dipersyaratkan oleh pemerintah yang telah ditetapkan dalam bentuk Undang-Undang, Peraturan Pemerintah dan Peraturan Daerah. Penanganan dalam proses pembuangan limbah menjadi suatu keharusan agar tercipta lingkungan yang bersih, sehat dan nyaman.

Proses Pengelolaan Air Limbah adalah suatu proses penyisihan zat-zat padat yang ada dalam air (terlarut, koloidal, tersuspensi) sebagai pencemar, sehingga tidak membahayakan bagi lingkungan dan mempunyai syarat yang ditetapkan oleh pemerintah. Dalam proses pengolahan limbah di PT.Apac Inti Corpora limbah yang dihasilkan lebih banyak berasal dari proses Dyeing.

Menurut Pak Bambang (karyawan WWE PT. Apac Inti Corpora) Unit Pengelolaan Limbah (WWTP) di PT.Apac Inti Corpora dilengkapi dengan susunan alat yang mendukung proses pengolahan limbah, yang terdiri dari: 1) Pengolahan Fisika, Sistem pengolahan fisika adalah pengolahan limbah cair yang digunakan untuk bahan bahan yang mudah mengendap dan senyawa organik yang tidak beracun dan tidak ada penambahan zat kimia. Macam-macam proses pengolahan fisika, Proses Screening: digunakan untuk menyaring atau memisahkan bahan-bahan tersuspensi/padat; Filter: dimana terdapat setelah proses pengolahan biologi yang didalamnya terkandung mikroorganisme dan juga menghasilkan pasir silika. 2) Pengolahan Kimia, Sistem Pengelolaan Kimia ini digunakan untuk menghilangkan serta menyaring limbah-limbah yang di dalamnya terdapat bahan yang tidak mudah menguap atau logam berat. 
Macam-macam pengolahan kimia: Proses Koagulasi - Flokulasi, Proses dengan menggunakan bahan pembantu yang disebut koagulan. Dimana kandungannya harus dipenuhi terlebih dahulu. Dalam proses koagulasi ini terdapat blower yang ada didasar bak, hal ini agar bahan padat tidak mengendap dibawah atau di samping-samping bak. Proses koagulasi dan flokulasi ini bertujuan untuk mrnghilangkan kekeruhan dan warna pada proses pengolahan air bersih. Flokulasi sendiri dilakukan setelah proses koagulasi. Flukolator berjalan lambat dengan maksud agar terjadi pembentukan flok.

Penambahan Elektrolit atau polimer, Untuk bahan-bahan tersuspensi bisa ditambahkan dengan bahan elektrolit yang mempunyai muatan berlawanan dengan muatan koloid yang netral sehingga mudah untuk diendapkan. Untuk menurunkan $\mathrm{pH}$ atau bahan kandungan dilakukan dengan pemberian Asam Sulfat dari $\mathrm{pH}$ berkisar 10,511 yang masuk ke dalam bak koagulasi menjadi 89 dimana itu sudah menjadi batas netral $\mathrm{pH}$. Dan hasil dari proses koagulasi ini menghasilkan flok kecil yang kemudian terikat menjadi flok-flok besar. Penyisihan logam berat dengan larytan Alkali.

Ditambahkan dengan larutan Alkali sehingga akan terbentuk endapan Logam Hidrosiadatif. Penyisihan Bahan Organik Beracun dapat diuraikan dengan oksidasi bahan-bahan oksidator menjadi bahan yang tidak berbahaya. 2) Pengolahan Biologi, Limbah cair yang mengandung limbah organik dapat diurai oleh mikroorganisme yang diolah secara biologi. Namun tidak semua bahanbahan organik dapat diolah dengan cara pengolahan biologi. Ada syarat-syarat yang harus dipenuhi, yaitu: a) pH mendekati netral; b) mempunyai temperatur yang sama dengan temperatur air; c) bahan organik yang susunan rantainya panjang; d) tidak tergolong bahan pembasmi mikroorganisme. 4) Tahapan Pengelolaan Limbah Cair, Pengelolaan Limbah Cair berdasarkan tahapan proses secara umum: a) perlakuan awal, penyaringan serpihan, pemisahan padatan, pemisahan lemak, b) perlakuan primer, Koagulasi dan flokulasi, Sedimentasi, Netralisasi, Proses lumpur aktif konvensional di aerasi.

\subsection{Kajian Hukum Tata Cara Pengelolaan Limbah}

PT. Apac Inti Corpora dalam menangani pengolahan limbah menggunakan Perda Provinsi Jawa Tengah Nomor 5 Tahun 2012 sebagai acuan. Perda Provinsi Jawa Tengah Nomor 5 Tahun 2012 tentang Perubahan Perda Provinsi Jawa Tengah Nomor 10 Tahun 2004 tentang Baku Mutu Air Limbah manyebutkan tentang ukuran atau standard untuk baku mutu air limbah bagi kawasan industri sebagai berikut:

Data yang tercantum dalam Perda Nomor 5 Tahun 2012 dan juga proses pengujian yang telah dilakukan Balai Besar Teknologi Pencegahan Pencemaran Industri (terdapat pada lampiran), maka PT. Apac Inti Corpora memenuhi syarat sesuai yang tercantum dalam Perda.

Pengujian-pengujian yang ketat dilakukan oleh Balai Besar Teknologi Pencegahan Pencemaran Industri (BBTPPI) untuk menjamin output pengelolaan limbah selalu memenuhi persyaratan dan berguna agar tidak terjadi implikasi/akibat yang timbul dikarenakan proses pengolahan limbah di PT. Apac Inti Corpora maupun hasil akhir dari proses pengolahan limbah. Pengujian ini berupa pemeriksaan terhadap limbah di Unit Pengelolaan Air Limbah (WWT/CWT) PT. Apac Inti Corpora setiap bulannya. Dari penelitian ini dapat diketahui bahwa PT. Apac Inti Corpora menghasilkan 2 macam jenis limbah B3, yaitu: 1) Limbah Cair, Ada beberapa sumber yang menghasilkan limbah cair, diantaranya: Majun, Dyeing, Sizing, Finishing, Laundry, WWT Laboraturium, Water Scruber Boiler Incenerator, Regenerasi resin, Filtrat declare, Cucian kemasan limbah B3. 2) Limbah Padat, PT. Apac Inti Corpora menghasilkan limbah 
padat B3 yang berbentuk pasir. Namun sebelum berbentuk pasir limbah padat ini berupa lumpur. Lumpur ini dikeringkan dengan menggunakan BVG dan gas. Hal ini dikarenakan limbah padat tidak dapat dibuang ke lingkungan sehingga PT. Apac Inti Corpora memberikan kepada pihak ketiga dimana dalam hal ini yang bersangkutan adalah PT. Terang Jaya. Dalam hal penyerahan limbah padat yang sudah berbentuk pasir ini diharuskan ada bukti penyerahan agar limbah tidak salah gunakan. Pengertian penyimpanan limbah B3 sendiri yaitu kegiatan menyimpan limbah B3 yang dilakukan oleh penghasil dan/atau pengumpul dan/atau pemanfaat dan/atau pengolah dan/atau penimbun limbah B3 dengan maksud menyimpan sementara.

Proses pengolahan limbah di PT.Apac Inti Corpora dirasa memiliki hambatan dalam masalah Cost (biaya) karena untuk industri besar seperti PT.Apac Inti Corpora memerlukan peralatan dalam pengolahan limbah yang tidak sedikit biayanya. PT. Apac Inti Corpora dahulu memiliki air pendingin untuk pemanfaatan kembali limbah yang ada, namun diperlukan biaya tambahan un- tuk memiliki air pendingin. Selain itu untuk menunjang agar tidak terjadinya pencemaran maka diperlukan tenaga ahli yang benar-benar mengerti dalam hal pengolahan limbah sehingga hambatan yang dialami dapat diminimalisir dengan kemampuan yang mereka punya.

\section{Simpulan}

Faktor-faktor yangl mendorong anak melakukan tindakk pidana perkosaan adalah faktor psikologis, lfaktor keluarga serta faktor lingkungan dan faktor ekonomi, oleh sebab itu semua komponen yang ada harus ikut terlibat di dalam pembinaan dan tumbuh kembang anak, agar anak tidak melakukan perbuatan dari norma-norma yang ada.

Hakim anak dalam menjatuhkan putusan lterhadap anak yang melakukan tindak kejahatan perkosaan mendasarkan pertimbangan pada Landasan Yuridis, berupa peraturan perundangundangan yang terkait dengan tindak pidana yang dilakukan oleh anak antara lain: Kitab Undangundang Hukum Pidana (KUHP), kitab Undangundang hukum acara pidana (KUHAP), Undang-

\begin{tabular}{clc}
\hline NO & \multicolumn{1}{c}{ PARAMETER } & KADAR MAKSIMUM (mg/L) \\
\hline 1 & TSS & 150 \\
2 & BOD & 50 \\
3 & COD & 100 \\
4 & Sulfida & 1 \\
5 & Amonia $\left(\mathrm{NH}_{3}-\mathrm{N}\right)$ & 20 \\
6 & Fenol & 1 \\
7 & Minyak dan lemak & 15 \\
8 & MBAS & 10 \\
9 & Kadmium & 0,1 \\
10 & Krom Heksavalen $\left(\mathrm{Cr}^{6+}\right)$ & 0,5 \\
11 & Krom total $(\mathrm{Cr})$ & 1 \\
12 & Tembaga $(\mathrm{Cu})$ & 2 \\
13 & Timbal $(\mathrm{Pb})$ & 1 \\
14 & Nikel $(\mathrm{Ni})$ & 0,5 \\
15 & Seng (Zn) & 10 \\
16 & Ph & $6,0-9,0$ \\
17 & Debit maksimum & $0,8 \mathrm{~L} /$ detik/Ha lahan kawasan terpakai \\
\hline
\end{tabular}




\section{Jurnal Cakrawala Hukum, Volume 9 No. 2 Desember 2018}

ISSN PRINT 2356-4962 ISSN ONINE 2598-6538

undang Nomor 12 Tahun 1995 Tentabng Pemasyarakatan, Undang-undang Nomor 4 Tahun 1979 Tentang kesejahteraan anak, Surat Edaran Mahkamah Agung Nomor P.1/20 tgl 30 Maret 1991 Tentang Penjahat Anak, Tanggal 15 Februari 1959 Tentang saran untuk memeriksa perkara anak dengan pintu ltertutup Terhadap Anak-anak yang menjadi terdakwa, Undang-undang RI Nomor 23 Tahun 2002 Tentang Perlindungan anak, Undangundang RI nomor 35 tahun 2014 Tentang perubahan atas undang-undang nomer 23 tahun 2002 Tentang Perlindungan Anak, Undang-undang RI Nomor 11 Tahun 2012 Tentang Sistem Peradilan Pidana Anak. Di lsamping itu Hakim wajib mempertimbangkan laporan pembimbing kemasyarakatan, Hakim tidak boleh menjatuhkan kumulasi hukuman, dan batas maksimal hukuman yang dijatuhkan.

\section{Daftar pustaka}

Abdurrahman. 1983. Pengantar Hukum Lingkungan Indonesia. Bandung. Alumni.

Adi, Rianto. 2004. Metodologi Penelitian Sosial dan Hukum. Granit. Jakarta.

Erwin, Muhammad. 2008. Hukum Lingkungan Dalam Sistem Kebijaksanaan Pembangunan Lingkungan Hidup. Bandung. Refika Aditama.
Gatot P. Soemartono, R.M. 2004. Hukum Lingkungan Indonesia. Jakarta. Sinar Grafika.

Ginting, Perdana. 2007. Sistem Pengelolaan Lingkungan dan Limbah Industri.: Bandung. Yrama Widya.

Mitchell, Bruce. 2000. Pengelolaan Sumber Daya Lingkungan. Gadjah Mada Yogyakatrta. University Press.

Siahaan. 2008. Hukum Lingkungan. Jakarta. Pancuran Alam.

Soekanto, Soerjono. 1981. Pengantar Penelitian Hukum. Jakarta. UI Press.

Soemitro, Ronny Hanitijo. 1988. Metodologi Penelitian Hukum dan Jurimetri. Jakarta. Ghalia Indonesia.

Soerjono. 1996. Hukum Lingkungan dan Peranannya Dalam Pembangunan.: Jakarta. Rienika Cipta.

Subagyo, P.Joko. 1992. Hukum Lingkungan Masalah dan Penanggulangannya. Jakarta. Rineka Citra.

Sunarso, Siswanto. 2005. Hukum Pidana Lingkungan Hidup dan Proses Penyelesaian Sengketa Lingkungan Hidup. Jakarta. Rienika Cipta.

Sunggono, Bambang. 2003. Metodologi Penelitian Hukum. Jakarta.Raja Grafindo Persada.

Supardi. 1994. Lingkungan Hidup \& Kelestariannya. Bandung. Alumni.

Supriadi. 2006. Hukum Lingkungan Di Indonesia. Jakarta. Sinar Grafika. 